\title{
A description of the male of Geckobiella donnae Paredes- León, Klompen et Pérez, 2012 (Acari: Pterygosomatidae) from captive iguanas in Honduras
}

\author{
Stanislav Kalúz ${ }^{1}$ and Ivan Literák ${ }^{2}$ \\ ${ }^{1}$ Institute of Zoology, Slovak Academy of Sciences, Bratislava, Slovakia; \\ ${ }^{2}$ Department of Biology and Wildlife Diseases, Faculty of Veterinary Hygiene and Ecology, University of Veterinary and \\ Pharmaceutical Sciences Brno, Brno, Czech Republic
}

\begin{abstract}
Mites of the family Pterygosomatidae are usually infesting lizards, geckos and iguanas. In this family, the genus Geckobiella Hirst, 1917 comprises 12 species including Geckobiella donnae Paredes-León, Klompen et Pérez, 2012. We collected 48 mites of G. donnae from 10 captive iguanas Ctenosaura bakeri Stejneger (Reptilia: Iguanidae) out of 23 examined individuals (prevalence 43\% ) in Iguana Research and Breeding Station on Isla de Utila, Islas de la Bahía, Honduras on 1 September 2014. Males of G. donnae occurred together with females. The male of $G$. donnae is described here for the first time. We speculated that $G$. donnae is autochthonous on Isla de Utila with $C$. bakeri as a natural host or that it was transmitted to C. bakeri from Iguana iguana (Linnaeus) native to Utila or introduced to Utila from the North American/Central American mainland by a host kept as a pet.
\end{abstract}

Keywords: parasite, taxonomy, male, Prostigmata

The mite family Pterygosomatidae comprises about 180 species (Bochkov and O’Connor 2006, Fajfer 2012). Most of representatives of this family are permanent and highly specified ectoparasites of lizards, geckos and iguanas (Reptilia, Squamata) except for the genus Pimeliaphilus Trägardh including the species that are parasites of arthropods (Davidson 1958, Goldberg and Bursey 1994, Hoppmann and Barron 2007, Hunter and Barron 2007, Gutsche et al. 2012, Fajfer and Gonzáles-Acuňa 2013, Gomides et al. 2015)

Pterygosomatids are widely distributed in the world, but the most of papers dealing with mites of the family Pterygosomatidae came from the New Word (Walter and Shaw 2002, Paredes-León et al. 2008, Paredes-León and Pérez 2008, Paredes-León and Morales-Malacara 2009, Murgas et al. 2013, Quiroz-Gutiérrez et al. 2015).

Paredes-León et al. $(2012,2013)$ and Paredes-León and Guzmán-Cornejo (2015) published the papers dealing with the family Pterygosomatidae and presented the complexity of the knowledge of the taxonomy, morphology, types of the hosts and of positions of different species within the genus Geckobiella Hirst, 1917. The genus Geckobiella comprises 12 species (Paredes-León and Guzmán-Cornejo 2015). This paper brings the first description of the male of Geckobiella donnae Paredes-León, Klompen et Pérez, 2012 (see Paredes-León et al. 2012).

\section{MATERIALS AND METHODS}

The field collection of pterygosomatid mites was run simultaneously with the investigation of ticks in Honduras during 2014 (Novakova et al. 2015). Collections were undertaken on Utila Island, a small Caribbean island $33 \mathrm{~km}$ from the mainland of Honduras $\left(16^{\circ} 06^{\prime} \mathrm{N} ; 86^{\circ} 54^{\prime} \mathrm{W}, 25 \mathrm{~m}\right.$ a.s.1.) and characterised by mangrove forest, wetlands, remnants of broadleaf forest, and pastures.

Pterygosomatid mites were collected from captive iguanas Ctenosaura bakeri Stejneger $(\mathrm{n}=23)$ and Iguana iguana (Linnaeus) $(\mathrm{n}=1)$ at the Iguana Research and Breeding Station at Utila on 1 September 2014. Mites were attached mostly on head (including tympaneum - see Fig. 1), neck and legs and were collected by Ivan Literák and Luis Chevez.

The mites attached to iguanas were collected during naked-eye examination using tweezers and then preserved in $96 \%$ ethanol. All mites collected were mounted into permanent slides using Liquide de-Swan medium (distilled water, $20 \mathrm{ml}$; arabic gum, $15 \mathrm{~g}$; chloral hydrate $50 \mathrm{~g}$ and glucose $3 \mathrm{~g}$, glacial acetic acid 5 ml; Kramár 1953) and observed under a light microscope. Pterygosomatid mites were identified according to Paredes-León et al. (2012). The drawings of the male of Geckobiella donnae were made using a drawing tube on a Zeiss Ergaval microscope (Carl Zeiss Jena, Jena, Germany), then edited by computer using GIMP2 software. For each leg the length was measured from the base of the coxal plate to the tip of the tarsus (excluding ambulacrum). Papers by Baker (1998), Cruz (1984), Cunliffe (1949,

Address for correspondence: I. Literák, Department of Biology and Wildlife Diseases, Faculty of Veterinary Hygiene and Ecology, University of Veterinary and Pharmaceutical Sciences Brno, Palackého 1946/1, 61242 Brno, Czech Republic. Phone: +420 541562630 ; Fax: +420 541 562 631; E-mail: literaki@vfu.cz 


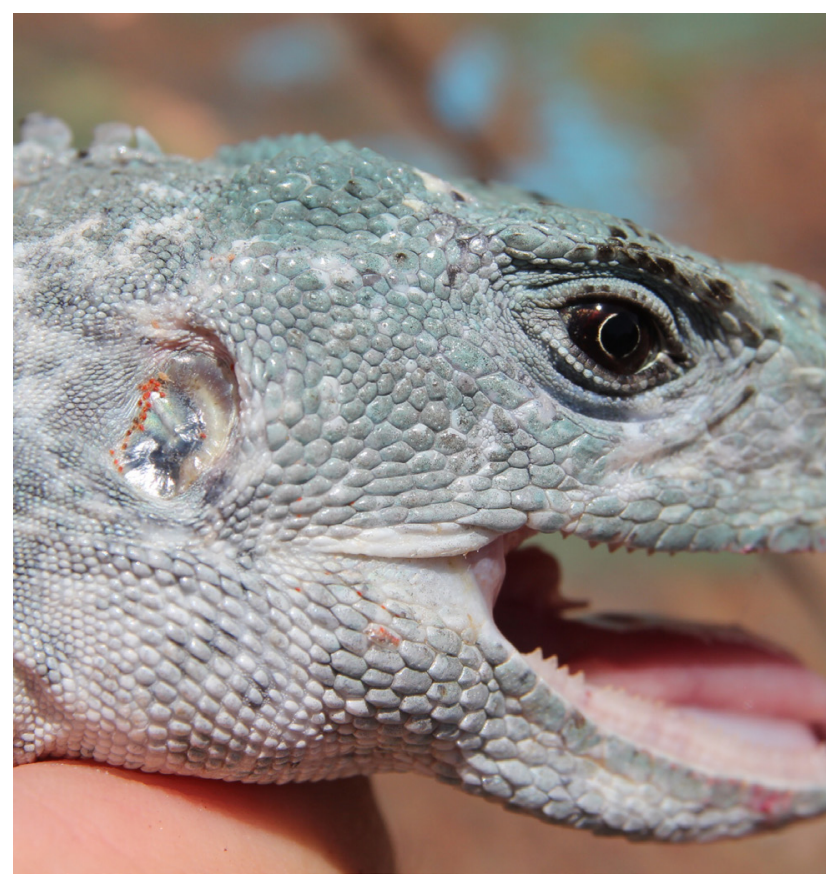

Fig. 1. Geckobiella donnae Paredes-León, Klompen et Pérez, 2012 on a head of Ctenosaura bakeri Stejneger, Honduras (photographed by Alberto Velasques).

1952), Jack (1961), Newell and Ryckman (1964), Paredes-León et al. (2012), Paredes-León and Guzmán-Cornejo (2015) were used for the taxonomic study to compare the differences in features of known males of species of Geckobiella. Terminology follows Jack (1964), Norton (1977), later adapted by Bochkov and O'Connor (2006), Krantz and Walter (2009), and Paredes-León et al. (2012). All measurements are in micrometres.

Voucher specimens of males of G. donnae are deposited in the Slovak National Museum, Bratislava, Slovakia (10 individuals), Natural History Museum, London, UK (5 individuals), Royal Belgian Institute of Natural Sciences, Brussels, Belgium (5 individuals). Other examined mites are deposited in the personal collection of the first author.

\section{RESULTS}

Geckobiella donnae Paredes-León, Klompen et Pérez, 2012

Material examined: 48 mite individuals (35 males, 13 females) of $G$. donnae were collected from 10 captive iguanas Ctenosaura bakeri $(\mathrm{n}=23$, prevalence $43 \%$ ) on 1 September 2014. Locality: Iguana Research and Breeding Station $\left(16^{\circ} 06^{\prime} \mathrm{N}\right.$; $\left.86^{\circ} 53^{\prime} \mathrm{W}\right)$, Utila, Isla de Utila, Islas de la Bahía, Honduras. Males of $G$. donnae occurred together with females (Fig. 1) and no other mites were found on these hosts.

Description of male (format follows Paredes-León et al. 2012)

Gnathosoma (Fig. 2). Subcapitulum with simple hypostome, not expanded at apex, 1 pair of slender and smooth setae $(n)$ inserted ventrally behind palps; palps slender. Palpal femur three times longer than tibia. Setal formula

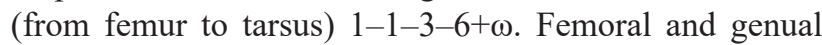

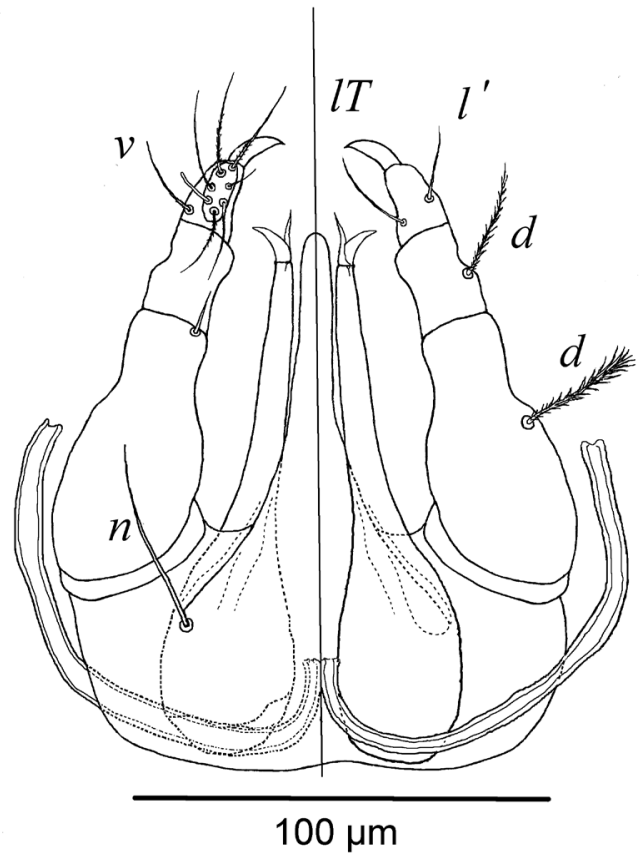

Fig. 2. Geckobiella donnae Paredes-León, Klompen et Pérez, 2012 from Ctenosaura bakeri Stejneger, Honduras. Male - gnathosoma - ventral (left), dorsal (right).

setae $d$ simple and of approximately same length, genual seta thinner; tibial setae $l^{\prime}$ smooth and simple, ventral tibial seta $v$ sparsely barbed; tibial claw simple and short (half of length of palpal tarsus); elongate tarsus narrowly attached to tibia, bears long basal solenidion $\omega$ and six setae: basal seta sparsely barbed proximally, three more distal setae smooth and simple, paraxial one much shorter than other setae, 1 apical seta smooth, simple and 1 apical seta sparsely barbed. Chelicerae long (anterior end reaches proximal part of palpal tibia), proximal part of cheliceral base globose and wide (six times wider than width of distal part); fixed digit membraneous, spiniform and movable digit robust and curved paraxially. Peritreme reaching half way along palpal femur.

Idiosoma (Figs. 3A,B). Clearly longer than wide; maximum width at level of setae $c 2$; dorsal cuticle surrounding setal platelets, coxae and sternal area striated.

Dorsum (Fig. 3A). Prodorsum without shield, with five pairs of plumose setae on platelets ( $v i$, ve, sci, and two similar setae designated as $c 3$ and sce, respectively - sensu Paredes-León et al. 2012 - Fig. 3c) that do not extend to next posterior row of setae, setae ve and $c 2$ the longest. Dorsal setae (each on platelet) plumose, prodorsal marginal lensed eye present on platelet anterior to lateral seta. Hysterosomal setae $c 1, c 2, d 1, d 2, e 1, e 2, f 1, f 2$ and $h 1$, present; setae composition like in female. Most dorsal setae plumose (except for barbed ps 1 and ps 2 figured on dorsal side). Lyrifissure ip located between seta $f 1$ and margin of hysterosoma. Anal area located on posterior tip, with sparsely barbed setae psland ps2, and with $p s 3$ seta (figured on ventral side) acuminate, nude.

Venter (Fig. 3B). Setae: coxal formula 2-2-4-1, setae located on coxae I-IV except for $3 a$ located on intercoxal 

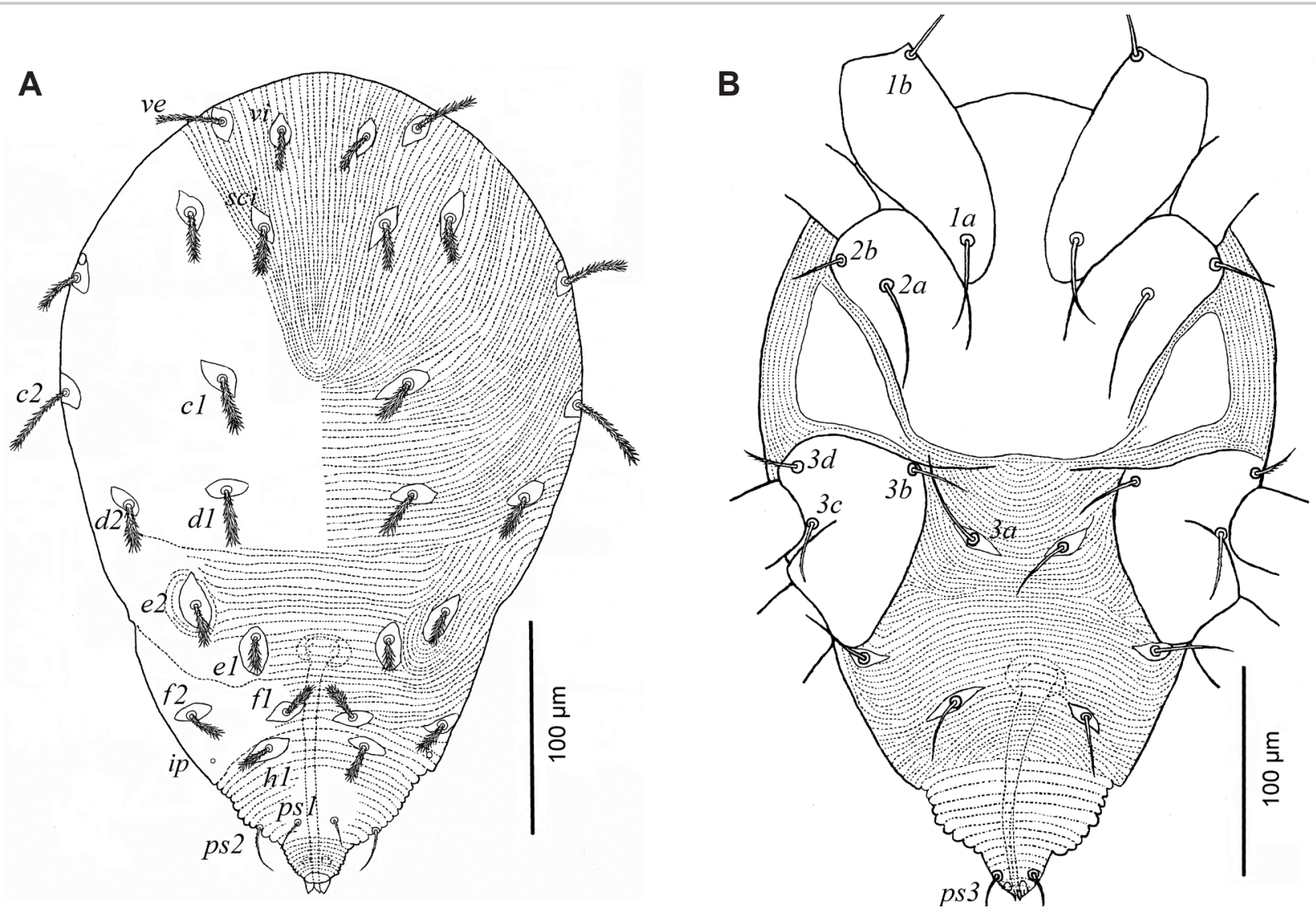

Fig. 3. Geckobiella donnae Paredes-León, Klompen et Pérez, 2012 from Ctenosaura bakeri Stejneger, Honduras. A - dorsal idiosoma of male; $\mathbf{B}$ - ventral idiosoma of male.

area, and undesignated seta close posteriad to coxae IV; ventral setae $1 a, 1 b, 2 a, 2 b, 3 a, 3 b$ smooth and slender, $3 c$ and $3 d$ sparsely barbed. Two pairs of remaining ventral setae (except ps3) slender and smooth, located laterad and posteriad from base of aedeagus, respectively. Aedeagus long and slender. Lyrifissure situated on lateral margin of hysterosoma (visible mainly ventrally) close to seta $p s 2$.

Legs (Figs 4A,B). Setal formulae (I-IV, microsetae $(\kappa)$ and solenidia in brackets): trochanter 1-1-1-0, femur

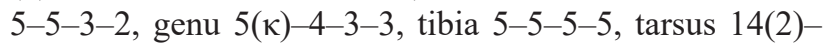
9(1)-9(1)-9.

Ventral setae $v$ on trochanters I and II acuminate, nude, $v$ seta on trochanter III plumose. All dorsal setae $d$ on femora-tibiae I-IV plumose and thicker than most of lateral and ventral setae. Leg I bears all ventral setae $v$ thin, acuminate and smooth. Smooth ventral setae occur also on tibia II, other leg segments bear these setae sparsely plumose or sparsely barbed. Most of lateral setae $l^{\prime}$ and $l^{\prime \prime}$ on all legs thinner and plumose except tibia I with setae $l^{\prime}$ and $l^{\prime \prime}$ long and smooth. Ventral seta $v^{\prime}$ on genu IV with thick stem, multibranched. Tarsus I with one pair of smooth setae $i t^{\prime}$ and $i t^{\prime \prime}$ at base of ambulacrum; also with sparsely barbed setae $u^{\prime}$ and $u^{\prime \prime}$. Solenidia of tarsus I long, $\omega 2$ longer than $\omega 1$ but shorter than companion seta $f t$. Tarsus I also with a pair of long smooth setae $t c^{\prime}$ and $t c^{\prime \prime}$ subequal in length; setae $t c^{\prime}$ II-IV slightly barbed, shorter than $t c^{\prime} I ; t c^{\prime}$ II-IV longer than $t c^{\prime \prime}$ II-IV. Setae $p^{\prime}$ and $p^{\prime \prime}$ on tarsi II-IV thin and slightly barbed or thin plumose; setae $p^{\prime}$ and $p^{\prime \prime}$ on tarsus I seem smooth; setae $a^{\prime}$ and $a^{\prime \prime}$ on all tarsi thicker, plumose.
Solenidia on tarsi II-III much shorter than solenidia on tarsus I, seta $v s^{\prime \prime}$ on tarsus I present, but II-IV absent on tarsi.

Measurements. Altogether ten male individuals measured (mean followed in parentheses by range). Length of idiosoma (gnathosoma excluded) 426 (370-513), idiosoma maximum width 261 (226-294), aedeagus length 125 (108-158), width between setal pair vi 46 (40-57), width between setal pair ve 114 (96-124), width between setal pair sci 68 (59-75); setal lengths: vi 23 (20-27), ve 31 (27-36), sci 23 (20-25), leg lengths (excluding ambulacrum): leg I 601 (479-691), leg II 333 (274-357), leg III 349 (274-389), leg IV 399 (327-423); solenidion $\omega 1$ of tarsus I length 47 (39-60), solenidion $\omega 2$ of tarsus I length 55 (39-62), ft (companion seta of solenidion $\omega 2$ of tarsus I) length 88 (82-103), solenidion $\omega$ of tarsus II length 21 (18-24), solenidion $\omega$ of tarsus III length 3 (3-4); subcapitulum length (from mid-point of posterior margin to tip of hypostome) 134 (121-151), base of subcapitulum width 93 (81-107), subcapitular setae $n$ length 40 (30-50), length of chelicerae 125 (109-138), width of chelicerae (at base) 27 (24-32), palp length 94 (80-103), palp width 27 (24-29), palp-claw length $10(8-11)$, and peritreme length (both members of pair) 203 (194-220).

Measurement of female Ten females (mean followed in parentheses by range). Length of idiosoma (gnathosoma excluded) 678 (600-796), idiosoma maximum width 425 (382-480), length of prodorsal shield 227 (205-260), width of prodorsal shield 119 (108-135), width between setal pair vi 85 (75-92), width between setal pair ve 211 

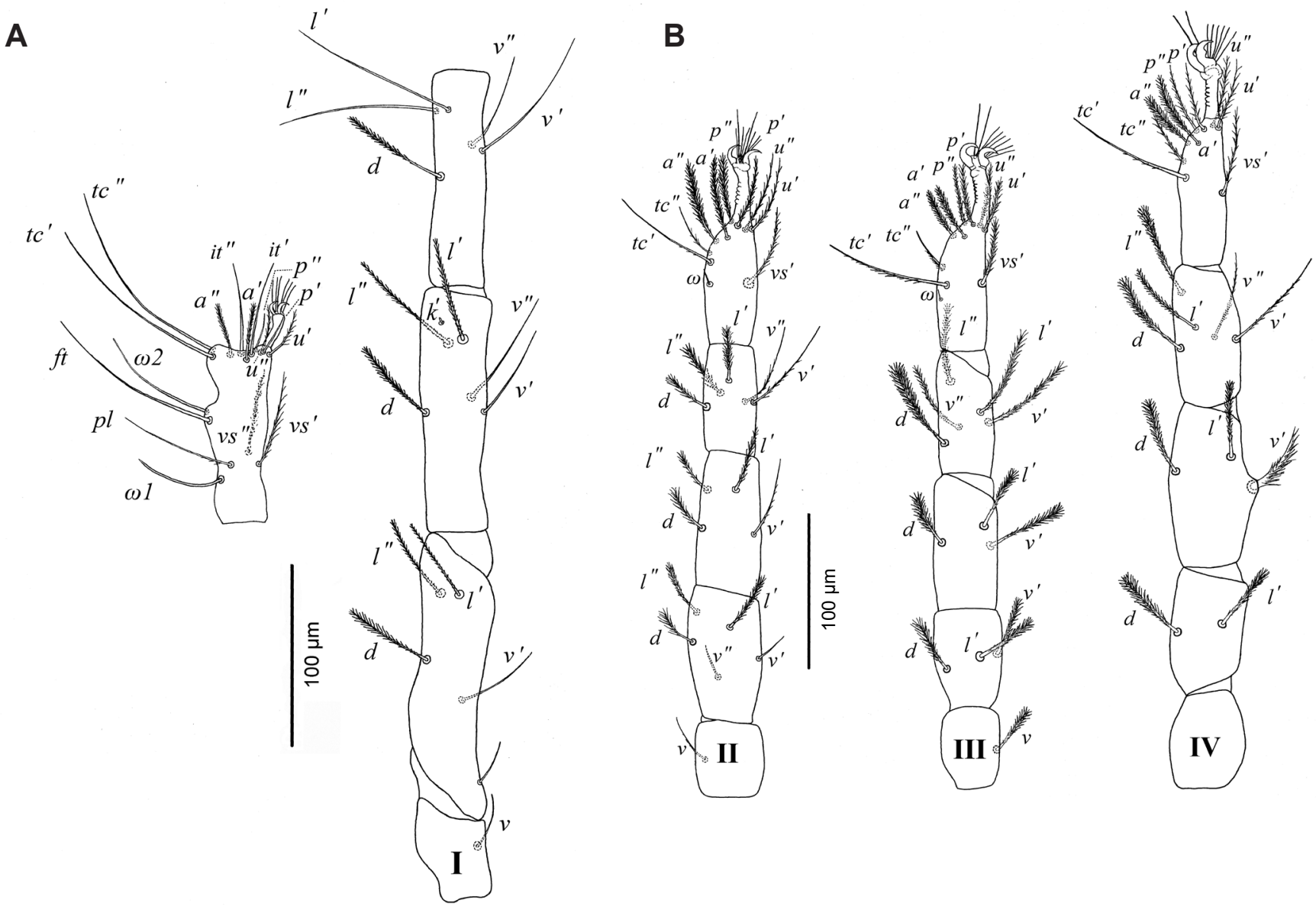

Fig. 4. Legs (I-IV) of male of Geckobiella donnae Paredes-León, Klompen et Pérez, 2012 from Ctenosaura bakeri Stejneger, Honduras. A - leg I, dorsolateral view; B - legs II - IV, dorsolateral view.

(190-225), width between setal pair sci 150 (145-156); setal lengths: vi 38 (35-42), ve 56 (48-65), sci 45 (37-50); leg lengths (excluding ambulacrum): leg I 657 (575-715), leg II 481 (430-523), leg III 500 (425-561), leg IV 525 (483-575); solenidion $\omega 1$ of tarsus I length 67 (60-76), solenidion $\omega 2$ of tarsus I length 77 (65-84), ft (companion seta of solenidion $\omega 2$ of tarsus I) length 113 (96-123), solenidion $\omega$ of tarsus II length 40 (34-50), solenidion $\omega$ of tarsus III length 15 (12-20); subcapitulum length 299 (281-325), base of subcapitulum width 130 (125-135), subcapitular setae $n$ length 75 (60-83), length of chelicerae 256 (240-274), width of chelicerae (at base) 40 (30-43), palp length 235 (210-255), palp width 37 (34-40), palpclaw length 15 (15-18), and peritreme length (both members of the pair) 402 (340-447).

Remarks. The male of $G$. donnae is close to the male of Geckobiella stamii (Jack, 1961), sharing the dorsal area striated over its entire surface and also the absence of prodorsal shield. In $G$. stamii setae vi are the most anterior dorsal setae, folowed by ve that are closer to sci. Setae $d 2$ and $e 2$ differ from dorsal setae, they are shorter, thinner and more spiked. Palpal femoral seta $d$ forms a stout, short and five-pronged fork. Femur I is lacking setae $l^{\prime}$, $l^{\prime \prime}$ (Paredes-León et al. 2012). The male of G. donnae has prodorsal setae ve placed at a more anterior position than $v i$ that are in the same row, and $s c i$ are situated in the second (more posterior) row. Setae $d 2$ and $e 2$ are of the same shape like the most of other dorsal setae. Palpal femoral seta $d$ is longer, slender and plumose. Setae $l^{\prime}, l^{\prime \prime}$ are present.

The male of another similar species Geckobiella pyriformis (Newell et Ryckman, 1964) differs from G. donnae having tibia I with solid spine-like seta $v^{\prime \prime}$, covered with short, spinose ornamentation, seta four to five times shorted than $v^{\prime}$. Geckobiella pyriformis bears 12 pairs of plumose apically pointed dorsal setae ( $f 2$ and $h 1$ absent). In male of $G$. donnae, tibia bears both setae $v^{\prime}$ and $v^{\prime \prime}$ attenuate and much longer. Geckobiella donnae bears 14 pairs of much broader plumose dorsal setae ( $f 2$ and $h 1$ present), not apically pointed.

The male of $G$. donnae differs from Geckobiella diolii (Baker, 1998) by seta $d$ on palpal femur longer plumose, by 14 pairs of plumose dorsal setae ( $f 2$ and $h 1$ present) setae (one third to one half) thicker than in male of $G$. diolii and by all dorsal setae located on area with striation. The male of $G$. diolii bears seta $d$ on palpal femur short, almost conical; it also differs from $G$. donnae by 12 pairs of dorsal setae ( $f 2$ and $h l$ absent), and by hysterodorsal setae $d 1, e l$ and $f l$ located on area lacking striation.

The male of G. donnae differs from that of Geckobiella javieri (Cruz, 1984) by longer plumose seta $d$ on palpal femur, by 14 pairs of plumose dorsal setae ( $f 2$ and $h 1$ present) and by all dorsal setae located on area with striation. 
The male of $G$. javieri has palpal femur with short, almost conical seta $d, 12$ pairs of dorsal setae ( $f 2$ and $h 1$ absent), and hysterodorsal setae $d 1, e 1, e 2$ and $f 1$ located on area without striation.

The male of $G$. donnae differs from a similar male of Geckobiella bakeri (Cunliffe, 1952) having femur and tibia of palpus with dorsal setae $d$ about same length, venter of tibia IV with setae $v$ long sparsely barbed. Geckobiella bakeri has dorsum of palpal femur with short, club-like spined seta $d$, palpal tibia with normal pilose seta $d$ about twice as long as that on femur, and venter of tibia IV with seta $v^{\prime \prime}$ small, short triangular spine-like.

The male of G. donnae differs from the male of Geckobiella boneti (Cunliffe, 1952) having 14 pairs of plumose dorsal setae, genua by seta $d$ on palpal femur longer plumose. Seta $v^{\prime \prime}$ on tibia IV is thin, sparcely barbed. Geckobiella boneti has 12 pairs of thinner plumose dorsal setae, and genua with seta $d$ on palpal femur strong, short, almost conical. Seta $v^{\prime \prime}$ on tibia IV is solid and spine-like (Paredes-León et al. 2012).

Three other similar species, Geckobiella harrisi Davidson, 1958, Geckobiella texana (Banks, 1904) and Geckobiella variabilis Paredes-León et Guzmán-Cornejo, 2015 (see Banks 1904), differ from the male of $G$. donnae by hypertrichous dorsal setation and by trochanter setal formula 1-1-1-1, while the dorsum of $G$. donnae is hypotrichous and trochanter setal formula is 1-1-1-0 (Paredes-León and Guzmán-Cornejo 2015). In two remaining species, Geckobiella pelaezi (Cunliffe, 1949) and Geckobiella trombidiformes Berlese, 1920, the males are unknown (Hoffmann and López-Campos 2000).

\section{DISCUSSION}

Most morphological features in both sexes of Geckobiella donnae from Honduras are identical - shape and position of setae on body and legs, setal formulae on legs and palps, including much shorter palpal tarsal paraxial seta both in male and female. The differences are: absence of prodorsal shield in smaller male, absence of $v$ seta on trochanter IV and smooth ventral setae $v$ on leg I, whereas female has prodorsal shield, bears ventral seta $v$ on trochanter IV, and $v$ setae on leg I are barbed, not smooth. In females analysed femur II bears four setae, whereas in males some individuals have five setae (as in Fig. 4B).

The females of Geckobiella donnae from Honduras were compared with those from the original description of female (Paredes-León et al. 2012) collected from captive iguanas in a pet store in USA. Our comparison show (morphological characters, setal formulae and measurements) that the females from both collections belong to the same species. The same 29 characters in ten Honduran females were measured as in five females published by Paredes-León et al. (2012). Generally, the females from the USA were larger in body size, the range of values in 13 characters were higher (e.g. length of $v i$, width between setal pair $s c i-s c i$, length of leg IV...) compared to Honduran females, while in three characters (e.g. width between setal pair $v i-v i$, width between setal pair $s c i-s c i$, length of $\omega$ on Ta III ) were lower. In contrast, the ranges of values in 13 remaining characters were common for both materials. So far a few females were measured and a wider comparison is impossible. However, we suppose that a wider range of more features measured indicates noticeable morphological plasticity of the species.

The original description of $G$. donnae was based only on seven females collected from captive Iguana iguana from a pet store in the USA, with one paratype female from Ctenosaura pectinata Wiegmann originating from Mexico (Paredes-León et al. 2012). It seems that G. donnae is highly prevalent on Ctenosaura bakeri on the small Isla de Utila in the Caribbean Sea (Gutsche et al. 2012). We found these mites with a prevalence of $43 \%$ on the captive C. bakeri examined but none was found on the one I. iguana examined from the same rescue facility. Moreover, C. bakeri on Isla de Utila were examined for ectoparasites in 2010 and 2011 (Faulkner 2011); pterygosomatid mites presumably of Geckobiella sp. (originally identified as Hirstiella sp., but this genus is regarded as a junior synonym of Geckobiella by Paredes-León et al. 2012) were found frequently on both captive $C$. bakeri (prevalence $42 \%$, from the same rescue facility as in our study) and wild C. bakeri (57\%).

We speculate that $G$. donnae is autochthonous on Isla de Utila with $C$. bakeri as a natural host (the most probable scenario) or that it was transmitted to C. bakeri from I. iguana native to Utila or introduced to Utila from the North American/Central American mainland by a host kept as a pet.

Acknowledgements. We thank Alberto Andres Velasques Castillo and Miroslav Valan, students at the University of Veterinary and Pharmaceutical Sciences Brno, Czech Republic, for their co-operation in the field and/or in the laboratory. We thank Luis Chevez from Bay Island Foundation, Iguana Station, Utila, Islas de la Bahía, Honduras for his co-operation during sampling of mites on reptiles at Iguana Station in Utila. The field study was permitted by the Instituto Nacional de Conservación y Dearrolo Forestal, Área Protegidas y Vida Silvestre, Gobierno de la República de Honhuras (RESOLUCIÓN-DE-MP-063-2014). The study was supported partially by grant VEGA 2/0139/17. We are grateful to anonymous reviewers for their comments and valuable advices.

\section{REFERENCES}

BAKer A. 1998: A new species of Hirstiella Berlese (Acari: Pterygosomatidae) from captive rhinoceros iguanas, Cyclura cornuta Bonnaterre (Reptilia: Iguanidae). Syst. Appl. Acarol. 3: 183-192.

Banks N. 1904: A treatise on the Acarina, or mites. Proc. U.S. Nat. Mus. 28: 1-114.
Berlese A. 1920: Centuria quinta di Acari nuovi. Redia 14: 143-195. Bochкov A.V., O'Connor B.M. 2006: [A review of the external morphology of the family Pterygosomatidae and its systematic position within the Prostigmata (Acari: Acariformes).] Parazitologiya 40: 201-214 (In Russian). 
Cruz J. De La. 1984: Sistemática de la familia Pterygosomidae (Acarina: Prostigmata), con la descripción de un nuevo género y especie. Poeyana 278: 1-22.

Cunliffe F. 1949: Hirstiella pelaezi, a new lizard parasite from Mexico. Proc. Entomol. Soc. Wash. 51: 25-26.

Cunliffe F. 1952: Biology of the cockroach parasite, Pimeliaphilus podapolipophagus Tragardh, with a discussion of the genera Pimeliaphilus and Hirstiella. Proc. Entomol. Soc. Wash. 54: 153-169.

DAvidson J.A. 1958: A new species of lizard mite and generic key to the family Pterygosomidae (Acarina, Anystoidea). Proc. Entomol. Soc. Wash. 60: 75-79.

FAJFER M. 2012: Acari (Chelicerata) - parasites of reptiles. Acarina 20: $108-129$.

Fajfer M., GonzÁles-AcuŇa D. 2013: Pterygosomatid mites of a new species group ligare (Acariformes: Pterygosomatidae: Pterygosoma) parasiting tree iguanas (Squamata: Liolaemidae: Liolaemus). Zootaxa 3693: 301-319.

FAULKNER S. 2011: Ectoparasite Abundance and Infestation Prevalence in Relation to Sex, SVL Length and Seasons of Ctenosaura bakeri; an Endemic Iguanid of Utila - with Notes on Three New Host Species of Helminth. Biological Sciences. Isla de Utila, Honduras, $35 \mathrm{pp}$

Goldberg S.R., BURSey C.R. 1994: Prevalence of ectoparasites infestation in neonate Yarrow spin lizard Sceloporus jarrovii (Phrynosomatidae) from Arizona. Great Basin Nat. 54: 189-190.

Gomides C., Maturano R., Daemon E., De Anchieta Garcia P. C., Rodrigues M.T. 2015: New reports of Acari ectoparasites on lizards of the genus Plica (Squamata: Tropiduridae) and a list of parasites known from this genus. Salamandr 51: 195-198.

Gutsche A., Mutschmann F., Streich W.J., Kampen H. 2012: Ectoparasites in the endangered Utila spiny-tailed iguana (Ctenosaura bakeri). Herpetol. J. 22: 157-161.

Hoffmann A. Y. G., López-Campos G. 2000. Biodiversidad de los ácaros en México. CONABIO y UNAM, México, D.F., 230 pp.

Hoppmann E., Barron H. W. 2007: Dermatology in reptiles. J. Exot. Pet Med. 16: 210-224.

Hunter E., Barron R. 2007: A new species of mite, genus Hirstella (Acari: Pterygosomatidae) from the banded gecko, Coleonyx tariegayus, of Western North America. J. Kansas Entomol. Soc. 39: 681-687.

JACK K.M. 1961: A re-examination of the genera Pimeliaphilus Trägårdh 1905 and Hirstiella Berlese 1920 (Acari; Prostigmata). Ann. Mag. Nat. Hist. 4: 305-314.

JACK K.M. 1964: Leg chaetotaxy with special reference to the Pterygosomidae (Acarina). Ann. Natal Mus., Pietermaritzbg. 16: 152-171.

KramÁ $̌$ J. 1953: [The contribution to microscopic preparation of arthropods.] Českoslov. Biol. 2: 57-58. (In Czech).

Krantz G.W., Walter D.E. 2009 (Eds.): A Manual of Acarology. Texas Tech University Press, Lubbock, $807 \mathrm{pp}$.

Murgas D.A., Dutary S.R., Miranda R.J. 2013: First report of Geckobiella stamii (Acari: Pterygosomatidae) parasitising Iguana iguana (Squamata: Iguanidae) in Panama. Rev. Ibér. Aracnol. 22: 97-98.
Newell I.M., Ryckman R.E. 1964: Hirstiella pyriformis sp. n. (Acari, Pterygosomidae), a new parasite of lizards from Baja California. J. Parasitol. 50: 163-171.

Norton R.A. 1977: A review of F. Grandjean's system of leg chaetotaxy in the Oribatei and its application to the Damaeidae. In: D.L. Dindal (Ed.), Biology of oribatid mites. State University of New York, New York, pp. 33-62.

Novakova M., Literak I., Chevez L.F., Martins T.F., OgrzeWALSKA M., Labruna M.B. 2015: Rickettsial infections in ticks from reptiles, birds and humans in Honduras. Ticks Tickborne Dis. 6: 737-742.

Paredes-León R., Cuervo-Pineda N., Pérez T. M. 2013: Pterygosomatid mites from Cuba, with the description of a new species of Bertrandiella (Acari: Prostigmata: Pterygosomatidae). Rev. Mex. Biodivers. 84: 1142-1152.

Paredes-León R., García-Prieto L., Guzmán-Cornejo C., León-Régagnon V., Pérez T.M. 2008: Metazoan parasites of Mexican amphibians and reptiles. Zootaxa 1904: 1-166.

Paredes-León R., Guzmán-Cornejo C. 2015: A new species of pterygosomatid mite and its phylogenetic position within the genus Geckobiella (Acariformes: Prostigmata: Pterygosomatidae). Inter. Journ. Acarol. 41: 19-30.

Paredes-León R., Klompen H., Pérez T.M. 2012: Systematic revision of the genera Geckobiella Hirst, 1917 and Hirstiella Berlese, 1920 (Acari: Prostigmata: Pterygosomatidae) with description of a new genus for American species parasites on geckos formerly placed in Hirstiella. Zootaxa 3510: 1-40.

Paredes-León R., Moraless-Malacara J.B. 2009: A new species of the genus Hirstiella (Acari: Prostigmata: Pterygosomatidae) parasitic on Phyllodactylus bordai (Reptilia: Squamata: Gekkonidae) in Mexico. J. Med. Entomol. 46: 442-450.

Paredes-León R., Pérez T. M. 2008: Pterygosomatid mites (Acari Prostigmata) of Mexico. In: M. Bertrand, S. Kreiter, K.D. MCCoy, A. Migeon, M. Navajas, M.-S. Tixier, L. Vial (Eds.), Integrative Acarology - Proceedings of the $6^{\text {th }}$ European Congress of Acarology, Montpellier, 21-25 July 2008, European Association of Acarologists, Montpellier, pp. 229-236.

Quiroz-Gutiérrez C. G., Paredes-León R., RoldánRodríguez J., PÉrez T.M. 2015: Dos especies nuevas de ácaros de los géneros Geckobia y Bertrandiella (Acari: Prostigmata: Pterygosomatidae) ectoparásitos del gecko endémico Phyllodactylus microphyllus (Squamata: Phyllodactylidae) del cerro Campana, La Libertad, Perú. Rev. Mex. Biodivers. 86: 310-318.

Walter D.E., Shaw M. 2002: First record of the mite Hirstiella diolii Baker (Prostigmata: Pterygosomatidae) from Australia, with a new review of mites on Australian lizards. Aust. J. Entomol. 41: $30-34$. 